\title{
Identifikasi Lokasi Potensial Panen Air Hujan Menggunakan Indeks Kesesuaian Embung dan Sistem Informasi Geografi di Provinsi Jawa Timur Indonesia
}

\author{
(Identification of Locations for Potential Rainwater Harvesting Using the Conformity \\ Index of Embankments and Geographic Information Systems in East Java Province, \\ Indonesia)
}

\author{
I Putu Santikayasa ${ }^{*}$, Mauludiyyatus Syarifah ${ }^{1}$, dan Muh Taufik ${ }^{1}$ \\ ${ }^{1}$ Departemen Geofisika dan Meteorologi, Fakultas Matematika dan Ilmu Pengetahuan Alam, \\ Institut Pertanian Bogor. \\ Jl. Raya Dramaga, Kampus IPB Dramaga, PO BOX 220, Bogor, Jawa Barat Indonesia \\ * Penulis korespondensi: psantika@gmail.com
}

Diterima: 8 Agustus 2021

Disetujui: 31 Desember 2021

\begin{abstract}
The pond is one approach is water harvesting technology for the development of agricultural land in dry areas. In this study, we identify areas that have a high potential for building water harvesting ponds in East Java Province, Indonesia. GIS approaches are used for spatial analysis in calculating the ponds potential index based on climate, physical surface, and vegetation indicators. This index is calculated based on indicators, each of which is obtained from the surface parameter data. The results of the study show that the East Java Province is categorized as the "very suitable" and "appropriate" areas on water harvesting ponds suitability by 55\% and 23\%, respectively. These results show that the potential of the East Java area for developing water harvesting ponds is very high about $78 \%$ compared with the entire region. On the other hand, locations that are categorized as "not suitable" and "very inappropriate" are about $8.7 \%$ and 9.2\% compared with the total area of East Java Province. It can be concluded that climate, physical surface, and vegetation indicators are very important in determining the locations of water harvesting pond development in East Java Province.
\end{abstract}

Keywords: agriculture water management, water harvesting, precision agriculture, small dam suitability index, dryland farming water management

\section{PENDAHULUAN}

Peningkatan lahan pertanian yang diikuti oleh peningkatan kebutuhan air pada sektor domestik dan industri menyebabkan kompetisi antar penggunaan air pada ketiga sektor tersebut (Santikayasa et al., 2017; Sitompul \& Efrida, 2018). Peningkatan kebutuhan pangan pada dasarnya dapat dipenuhi dengan upaya peningkatan luasan lahan pertanian namun demikian penyediaan lahan pertanian memberikan tantangan karena ketersediaan lahan untuk pertanian yang semakin berkurang akibat alih guna lahan dari lahan pertanian menjadi pemukiman dalam memenuhi kebutuhan pemukiman bagi masyarakat (Djamhari, 2009; Harini et al., 2019; Santoso, 2015; Sudana, 2017). Ketersediaan lahan pada wilayah tertentu yang berpotensi untuk dikembangkan menjadi lahan pertanian memiliki kendala akibat terbatasnya ketersediaan air diwilayah tersebut.

Teknologi pertanian rendah air mampu digunakan dalam pengembangan wilayah-wilayah menjadi wilayah 
pertanian dengan ketersediaan air yang cukup (Budianto et al., 2020; Iglesias \& Garrote, 2018; Quist-Jensen et al., 2015; Salli, 2019; Sutrisno \& Heryani, 2019). Demikian juga halnya dengan teknologi pemanenan air menggunakan embung merupakan salah satu pendekatan dalam pengembangan lahan pertanian daerah kering. Hasil kajian efektivitas embung untuk pertanian menyebutkan bahwa teknologi pemanenan air menggunakan embung mampu meningkatkan ketersediaan air dan mampu meningkatkann produksi pertanian (Ginting et al., 2019; Krisnayanti, 2018; Priyoadi \& Setiawan, 2020). Kajian tersebut juga menjelaskan bahwa penempatan embung merupakan salah satu kunci keberhasilan pengembangan wilayah pertanian pada wilayah tersebut.

Berbagai pendekatan telah dilakukan untuk menentukan lokasi efektif pembangunan embung. Berbagai penelitian menyebutkan bahwa lokasi embung yang efektif dapat ditentukan dengan menghitung jumlah curah hujan wilayah, topografi dengan kemiringan tertentu dan berada pada wilayah yang memiliki kategori jenis tanah spesifik (Adrianto, 2017; Anjasmoro et al., 2016; Indriani et al., 2020). Metode pembobotan merupakan pendekatan sederhana dan efektif untuk menentukan lokasi penempatan embung sesuai dengan kriteria tertentu dengan hasil kriteria yang paling efektif. Penggabungan pendekatan analisis faktor fisik, pembobotan dan analisis spasial dalam sistem infomasi geografi atau geographical information system (GIS) merupakan pendekatan yang digunakan dalam penentuan kesesuaian suatu wilayah dengan mempertimbangkan kondisi keruangan wilayah tersebut.

Penelitian ini bertujuan untuk mengidentifikasi wilayah-wilayah yang memiliki potensi tinggi untuk pembangunan embung dalam pemanenan air di wilayah Provinsi Jawa Timur, Indonesia. Provinsi Jawa Timur merupakan wilayah yang memiliki karakter curah hujan rendah dengan luas lahan marjinal yang tinggi dan termasuk wilayah dengan sentra produksi pangan khususnya padi gogo dan jagung sehingga memiliki potensi pengembangan lahan pertanian (Anam et al., 2020; Prabowo et al., 2014; Soerjandono, 2019). GIS dalam penelitian ini digunakan untuk analisis spasial dalam menghitung indeks potensi wilayah pembangunan embung. Indeks ini dihitung berdasarkan indikator yang diperoleh dari nilai parameter permukaan. Masing-masing indikator diberikan bobot kemudian dianalisis untuk memperoleh nilai potensi wilayah untuk pembangunan embung.

\section{METODOLOGI}

Penelitian ini mengambil wilayah studi di Provinsi Jawa Timur Indonesia, yang terletak pada $9^{\circ} 0^{\prime}-4^{\circ} 50^{\prime} \mathrm{LS}$ dan $110^{\circ} 30^{\prime}-116^{\circ} 30^{\prime}$ BT. Provinsi Jawa Timur memiliki iklim tropis dengan suhu rata-rata berkisar $21-34^{\circ} \mathrm{C}$. Suhu tertinggi terjadi pada Oktober dan November (suhu sekitar $35.3^{\circ} \mathrm{C}$ ), dan terendah di bulan Agustus (suhu sekitar $19.3^{\circ} \mathrm{C}$ ) dengan kelembaban berkisar antara 39-97\%. Provinsi Jawa Timur pada umumnya memiliki curah hujan sekitar $1900 \mathrm{~mm}$ per tahun dengan musim hujan selama 100 hari (Misnawati et al., 2020; Ulfah \& Sulistya, 2015).

Dalam bidang pertanian, lahan kering di Provinsi Jawa Timur memiliki potensi besar untuk produksi pertanian. Provinsi Jawa Timur menjadi sentra produksi pagi gogo kedua di Pulau Jawa setelah Provinsi Jawa Barat dan menjadi sentra produksi jagung dengan produksi tertinggi di Indonesia. Selain itu, Jawa 
Timur juga menjadi sentra produksi kedelai, ubikayu, dan ubi jalar (Muslim, 2017; Winahyu, 2020).

\section{Penentuan Nilai Indeks}

Identifikasi lokasi embung dilakukan secara spasial menggunakan pendekatan indeks kesesuaian embung (IKE) yang dihasilkan dari nilai indikator. Indikator merupakan komponen penyusun indeks yang disusun berdasarkan parameter permukaan. Indeks dihitung berdasarkan tiga indikator yaitu indikator iklim (IKL), indikator fisik permukaan (IFP) dan indikator vegetasi (IVI) (Persamaan 1). Dalam penelitian ini, IKL disusun berdasarkan data curah hujan (CH), IFP dihitung berdasarkan data tekstur tanah (ST), jarak dari sungai (JS) dan kelerengan wilayah (SL) sedangkan IVI diperoleh dari data tutupan vegetasi (VI).

$$
I K E=\frac{(I K L+I F P+I V I)}{3}
$$

IKE memiliki nilai pada rentang 15 dengan nilai 1 merupakan wilayah yang memiliki tingkat kesesuaian paling rendah dan 5 merupakan wilayah dengan tingkat kesesuaian paling tinggi. Kemudian, IKE dikategorikan menjadi empat klas yaitu Sangat Tidak Sesuai, Tidak Sesuai, Sesuai dan Sangat Sesuai, dengan nilai pada masing-masing klas seperti yang dijabarkan pada Tabel 1 . Nilai 1 dan 2 dari IKE dikategorikan sebagai "tidak sesuai" karena wilayahwilayah yang memiliki nilai indeks 1 memang merupakan wilayah yang tidak sesuai baik berdasarkan indikator iklim, fisik permukaan maupun vegetasi. Sedangkan nilai indeks 2 mensyaratkan perlunya dilakukan langkah pendukung (sesuai bersyarat) sehingga dikelompokkan pada kategori tidak sesuai selama belum dilakukan langkahlangkah pendukung diwilayah tersebut.

Tabel 1 Klasifikasi Kesesuaian Pembangunan Embung Berdasarkan Nilai Indeks Kesesuaian Embung (IKE)

\begin{tabular}{lc}
\hline \multicolumn{1}{c}{ Kelas } & Indeks \\
\hline Sangat tidak sesuai & $1-2$ \\
Tidak sesuai & 3 \\
Sesuai & 4 \\
Sangat sesuai & 5 \\
\hline
\end{tabular}

Semua indikator hasil analisis indeks dievaluasi secara spasial menggunakan aplikasi GIS dengan raster analysis tools untuk menghasilkan data dalam format raster. Hasil analisis indeks berupa peta sebaran potensi wilayah pembangunan embung. Luasan untuk masing-masing tingkat kesesuaian pada masing-masing kondisi dievaluasi untuk memberikan nilai persentasi wilayah berdasarkan tingkat potensi berdasarkan indeks.

\section{Penentuan Nilai Indikator iklim (IKL)}

Indikator iklim merupakan indikator yang diperoleh dari kondisi iklim wilayah yang mempengaruhi ketersediaan air di wilayah kajian. Dalam penelitin ini, data curah hujan digunakan untuk menghitung nilai indikator iklim. Hal ini sejalan dengan penelitian yang menyebutkan nilai curah hujan mempengaruhi tingkat kesesuaian lahan lokasi pembangunan embung 
(Ammar et al., 2016; Indriani et al., 2020). Semakin tinggi curah hujan maka semakin tinggi potensi wilayah tersebut untuk dijadikan wilayah pembangunan embung. Demikian juga sebaliknya, semakin rendah jumlah curah hujan maka potensi wilayah tersebut untuk lokasi pembangunan embung semakin rendah.

Data curah hujan dalam penelitian ini diperoleh dari data Tropical Rainfall Measuring Mission (TRMM) - NASA selama periode tahun 2006 - 2015 yang diunduh dari laman giovanni.gsfc.nasa.gov dengan resolusi spasial $30 \times 30 \mathrm{~m}$. Proses pemotongan data wilayah hujan dilakukan untuk mendapatkan data pada wilayah kajian. Nilai IKL dihitung berdasarkan klasifikasi curah hujan untuk hidrologi (Taufik et al., 2016). Curah hujan tinggi memiliki nilai IKL tinggi karena pembangunan embung memerlukan masukan air langsung dari curah hujan dan demikian juga sebaliknya pada curah hujan rendah maka nilai IKL menjadi rendah. Curah hujan dikelompokkan menjadi 5 kategori yang bersesuaian dengan nilai IKL (Tabel 2)

Tabel 2 Nilai Klasifikasi Curah Hujan untuk Menentukan Nilai Indeks Kesesuaian Iklim (IKL)

\begin{tabular}{ccc}
\hline Curah Hujan $(\mathrm{mm} / \mathrm{tahun})$ & Nilai IKL & Kategori \\
\hline$<1000$ & 1 & Tidak Sesuai \\
$1000-2000$ & 2 & Sesuai Bersyarat \\
$2000-2500$ & 3 & Cukup Sesuai \\
$2500-3000$ & 4 & Sesuai \\
$>3000$ & 5 & Sangat Sesuai \\
\hline
\end{tabular}

\section{Penentuan Nilai Indikator Fisik Permukaan (IFP)}

Nilai IFP dihitung berdasarkan nilai analisis data tekstur tanah (ST), kelerengan (SL) dan jarak dari sungai (JS). Hal ini didasarkan pada hasil penelitian yang menyebutkan bahwa tekstur dan kedalaman tanah, topografi dan kondisi drainase merupakan komponen penting dalam penentuan lokasi potensial pemanenan air (Tumbo et al., 2013). Tekstur dan kedalaman tanah dianalisis dengan menggunakan data tekstur tanah, topografi dianalisis dengan nilai kelerengan dan drainase dianalisis dengan menggunakan data jarak dari sungai. Pendekatan perhitungan komponen drainase didasarkan pada asumsi bahwa semakin jauh suatu wilayah dari sungai maka semakin tinggi potensi kehilangan air melalui proses evapotranspirasi maupun infiltrasi yang mengindikasikan nilai drainase yang tinggi. Dengan demikian, semakin tinggi drainase, potensi wilayah untuk menjadi lokasi embung semakin rendah karena semakin banyak kehilangan air dan demikian juga sebaliknya. Berdasarkan nilai masingmasing parameter, IFP dihitung menggunakan Persamaan 2.

$I F P=\frac{(S T+S L+J S)}{3}$

Nilai ST, SL dan JS dikategorikan berdasarkan nilai pada masing-masing kategori yang disesuaikan dengan nilai indikator seperti pada Tabel 3, 4 dan 5 . 
Tabel 3 Nilai Klasifikasi Tekstur Tanah untuk Menentukan Nilai Indeks Kesesuaian Fisik Permukaan (IFP)

\begin{tabular}{ccc}
\hline Tekstur Tanah & Nilai IKL & Kategori \\
\hline Other Class & 1 & Tidak Sesuai \\
Sandy Clay Loam dan Sandy & 2 & Sesuai Bersyarat \\
Loam & & \\
Sandy Clay & 3 & Cukup Sesuai \\
Silty Clay / Clay Loam & 4 & Sesuai \\
Clay & 5 & Sangat Sesuai \\
\hline
\end{tabular}

Tabel 4 Nilai Klasifikasi Kelerengan untuk Menentukan Nilai Indeks Kesesuaian Fisik Permukaan (IFP)

\begin{tabular}{ccc}
\hline Kelerengan (derajat) & Nilai IKL & Kategori \\
\hline$<30$ & 1 & Tidak Sesuai \\
$18-30$ & 2 & Sesuai Bersyarat \\
$10-18$ & 3 & Cukup Sesuai \\
$5-10$ & 4 & Sesuai \\
$<5$ & 5 & Sangat Sesuai
\end{tabular}

Tabel 5 Nilai Klasifikasi Jarak dari Sungai untuk Menentukan Nilai Indeks Kesesuaian Fisik Permukaan (IFP)

\begin{tabular}{ccc}
\hline Jarak dari Sungai $(\mathrm{m})$ & Nilai IKL & Kategori \\
\hline$<125$ & 1 & Tidak Sesuai \\
$125-250$ & 2 & Sesuai Bersyarat \\
$250-350$ & 3 & Cukup Sesuai \\
$350-500$ & 4 & Sesuai \\
$>500$ & 5 & Sangat Sesuai \\
\hline
\end{tabular}

\section{Penentuan Nilai Indikator Vegetasi (IVI)}

Tutupan vegetasi mempengaruhi limpasan permukaan. Hal ini menjadi asumsi sehingga penelitian ini menggunakan indikator vegetasi dalam menentukan potensi pembangunan embung di wilayah penelitian. Semakin tinggi kerapatan vegetasi maka semakin tinggi kehilangan air oleh proses intersepsi, penyimpanan, dan infiltrasi sehingga mengurangi limpasan (Anjasmoro et al., 2016; Tumbo et al., 2013). Pembangunan embung lebih sesuai pada wilayah yang memiliki tingkat vegetasi rendah dibandingkan dengan wilayah yang memiliki tingkat vegetasi tinggi. Untuk mengevaluasi IVI, jenis tutupan lahan diklasifikasikan dalam 5 kategori bersesuaian dengan kemampuan vegetasi dalam melakukan proses intersepsi dan menympan air pada 
kanopi (Tabel 6). Masing-masing

kategori bersesuaian dengan nilai IVI.

Tabel 6 Nilai Klasifikasi Vegetasi untuk Menentukan Nilai Indeks Kesesuaian Vegetasi (IVI)

\begin{tabular}{ccc}
\hline Kategori Tutupan Lahan & Nilai IKL & Kategori \\
\hline Vegetasi hutan & 1 & Tidak Sesuai \\
Pohon terbuka dengan semak & 2 & Sesuai Bersyarat \\
Semak terbuka dengan pohon \\
menyebar & 3 & Cukup Sesuai \\
Semak belukar & 4 & Sesuai \\
Area pertanian/terbangun & 5 & Sangat Sesuai \\
\hline
\end{tabular}

\section{HASIL DAN PEMBAHASAN}

\section{Kesesuaian Faktor Iklim dalam \\ Penentuan Lokasi Embung di Provinsi Jawa Timur}

Provinsi Jawa Timur memiliki curah hujan tahunan sebesar $1365-2848$ mm dengan 5-10 bulan basah (BB) dan 2-7 bulan kering (BK). Hasil tersebut menunjukkan bahwa wilayah Provinsi Jawa Timur termasuk dalam tipe iklim A, $\mathrm{B}$ dan $\mathrm{C}$ menurut klasifikasi iklim Oldeman. Tipe A dan B dalam klasifikasi tersebut merupakan wilayah yang sesuai untuk tanam padi sepanjang tahun yang diselingi satu kali tanam palawija sedangkan klasifikasi tipe $\mathrm{C}$ merupakan wilayah yang sesuai untuk satu kali tanam padi dan dua kali tanaman palawija dalam setahun, dengan syarat palawija pada musim tanamn kedua tidak dilakukan pada musim kering (Nasution \& Nuh, 2019).

Hasil analisis menunjukkan terjadi perubahan pola curah hujan di wilayah Jawa Timur. Meskipun curah hujan cukup tinggi, namun curah hujan beberapa wilayah di Provinsi Jawa Timur mengalami penurunan. Penurunan terjadi dengan pola yang berbeda dari wilayah bagian barat ke wilayah bagian timur. Hasil ini sejalan dengan penelitian
(Rahayu et al., 2018) yang menyatakan perbedaan pola hujan di Pulau Jawa dipengaruhi oleh tipe iklim monsun di wilayah Jawa hingga Nusa Tenggara yang menghasilkan kondisi wilayah bagian timur lebih kuat dipengaruhi oleh angin dari Australia yang membawa sedikit uap air, sedangkan wilayah bagian barat dipengaruhi angin dari Asia yang membawa banyak uap air. Dampaknya terlihat pada pola hujan wilayah bagian barat memiliki curah hujan yang lebih tinggi dibandingkan wilayah timur Provinsi Jawa Timur.

Hasil evaluasi potensi lokasi wilayah pembangunan embung berdasarkan indeks kesesuaian iklim (IKL) yang didaasarkan pada data curah hujan tahunan di wilayah Provinsi Jawa Timur menunjukkan bahwa sebagian besar wilayah berada pada kategori "sesuai" (nilai IKL = 4) sebagai lokasi pembangunan embung. Hasil ini didukung oleh penelitian (Mahendra \& Noerhayati, 2019) yang menunjukkan bahwa kondisi curah hujan di wilayah Pulau Jawa khususnya Provinsi Jawa Timur memiliki potensi tinggi untuk dilakukan pemanenan air dalam upaya meningkatkan produksi pertanian. Namun demikian, kategori potensi berdasarkan IKL tersebar pada kategori "sesuai", "cukup sesuai" (nilai IKL=3) 
dan "sesuai bersyarat" (nilai $\mathrm{IKL}=2$ ) sehingga perlu upaya tertentu untuk mampu menampung air untuk dimanfaatkan dalam pertanian. Hal ini sangat dipengaruhi oleh pola musim hujan dan kemarau bulanan di wilayah tersebut. Namun demikian, secara keseluruhan nilai IKL untuk wilayah
Provinsi Jawa Timur bagian tengah memiliki tingkat kesesuaian dengan kategori "sesuai" dan "cukup sesuai" sebesar 22,1\% dan 53,8\%. Selain itu juga sebagian wilayah Provinsi Jawa Timur masuk dalam kategori "sesuai bersyarat" sebesar 24,1\% dibandingkan dengan total luasan wilayah (Gambar 1)

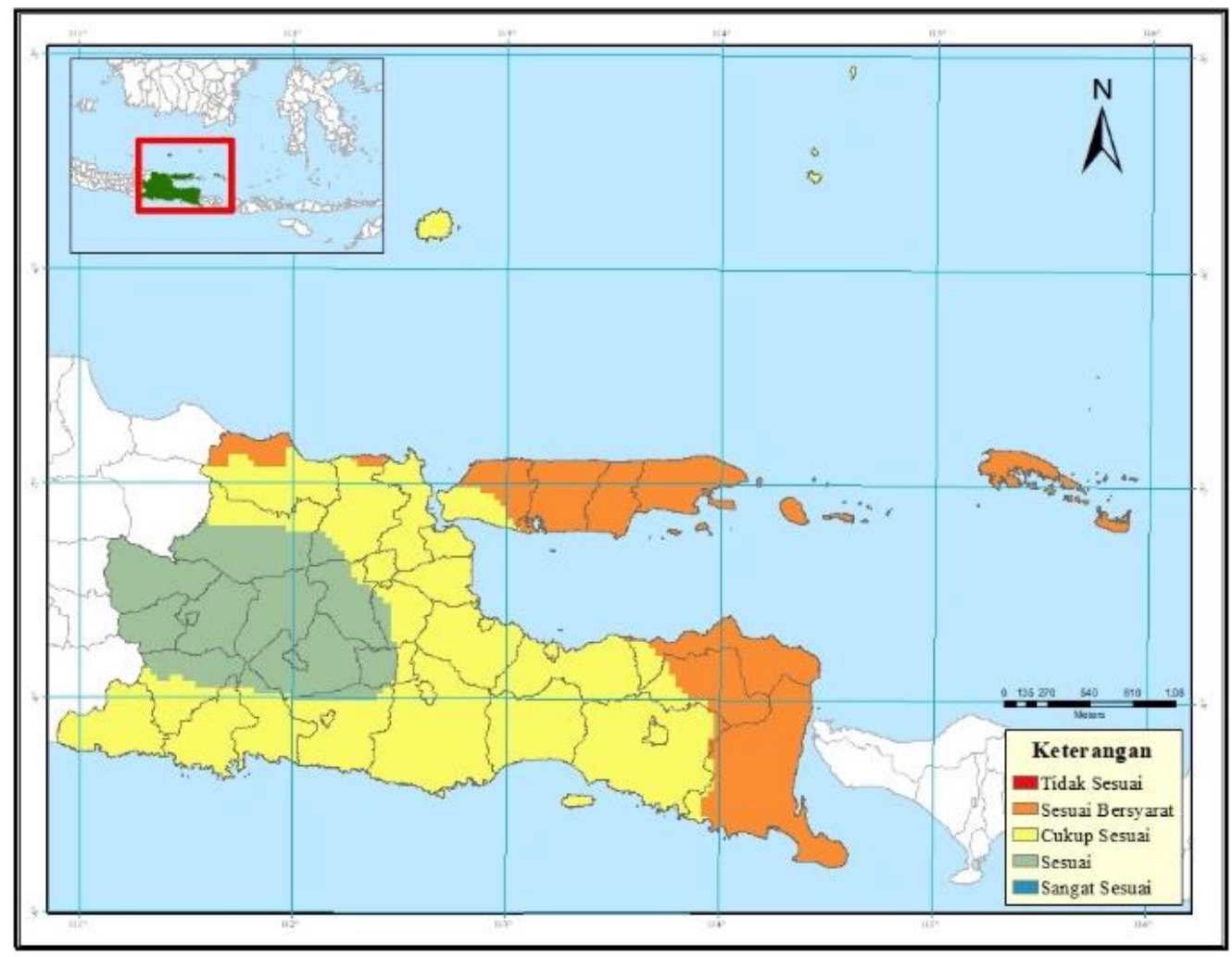

Gambar 1 Potensi Lokasi Pembangunan Embung Berdasarkan Nilai IKL

\section{Kesesuaian Faktor Fisik Permukaan dalam Penentuan Lokasi Embung}

Analisis pada komponen topografi menunjukkan bahwa Provinsi Jawa Timur memiliki topografi beragam dengan dominasi oleh dataran dengan kemiringan lereng rendah pada wilayah bagian utara dan dominasi oleh gunung dan pengunungan dengan kemiringan lereng lebih beragam dari landai hingga terjal pada wilayah bagian selatan. Hasil ini menunjukkan bahwa sekitar 71,9\% wilayah Provinsi Jawa Timur memiliki kategori "sesuai" menjadi lokasi pembangunan embung jika hanya didasarkan pada kondisi topografi. Pada sisi lain, lokasi dengan kategori "tidak sesuai" sampai dengan "cukup sesuai" tersebar dominan di wilayah bagian selatan sebesar 28,1\%. Sedangkan wilayah bagian utara didominasi oleh wilayah dataran rendah dengan potensi "sesuai" sebesar 25,9\% dan "sangat sesuai" sebesar 46\% (Gambar 2). Hal ini sesuai kajian (Tumbo et al., 2013) yang menunjukkan bahwa kelerengan wilayah sangat menentukan lokasi penentuan pembangunan embung serta jenis teknologi pemanenan air hujan yang digunakan. Pembangunan embung lebih sesuai berada di wilayah kemiringan 
lereng landai dengan kapasitas penahanan air tinggi dengan potensi tertinggi pada wilayah yang memiliki nilai kelerengan $<5 \%$ karena mampu menahan air lebih besar dan menerima limpasan air, sedangkan lebih dari itu menyebabkan lebih besar potensi kehilangan air dan erosi (Tala'ohu et al., 2013).

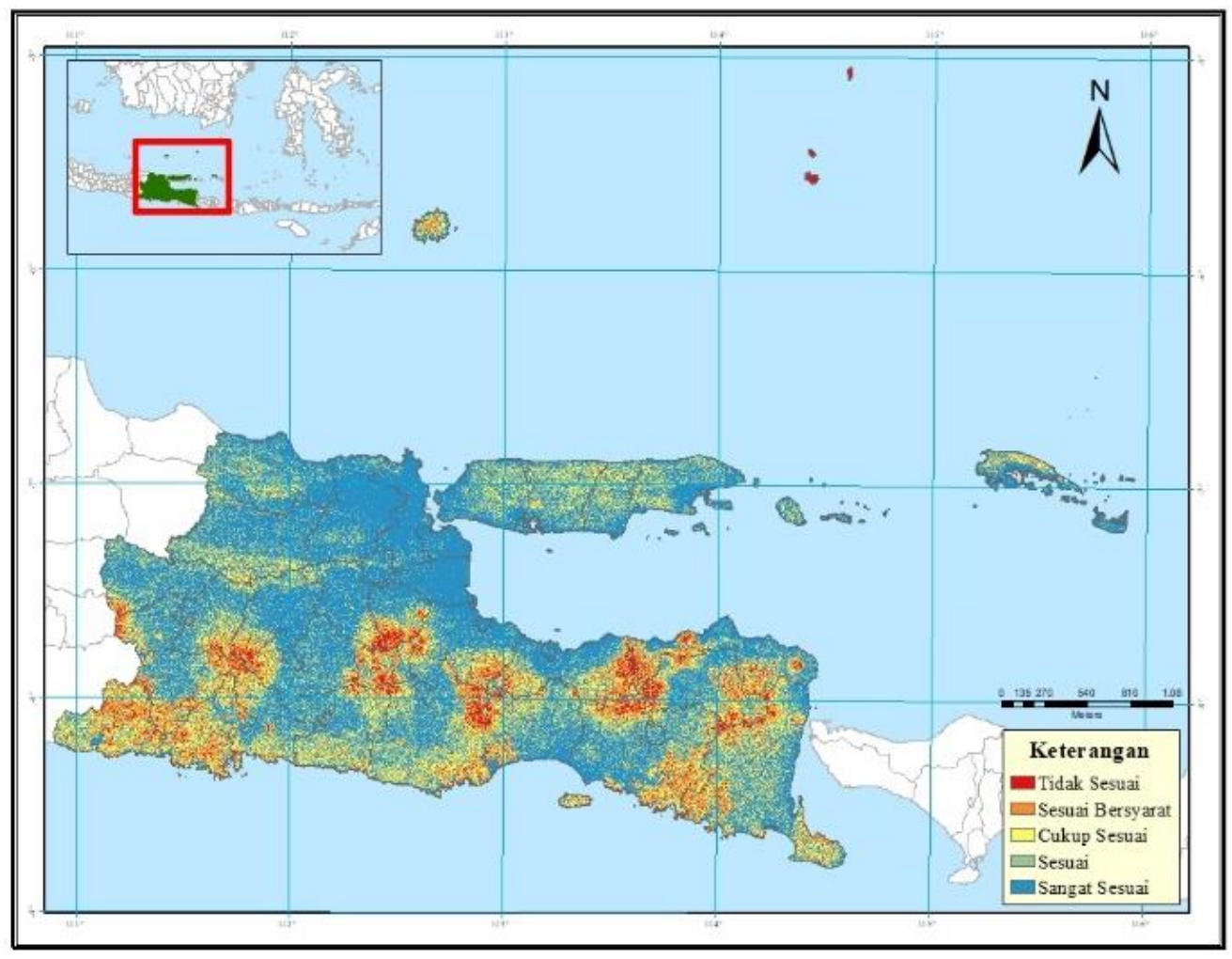

Gambar 2 Sebaran Nilai Indikator Kelerengan dalam Evaluasi Pembangunan Embung di Provinsi Jawa Timur

Pada sisi lain, tekstur tanah menentukan penyerapan air (infiltration) dan penyimpanan air (storage) di dalam tanah. Tekstur halus hingga menengah lebih sesuai untuk pemanenan air karena memiliki kemampuan penyimpanan yang tinggi (Hermawan et al., 2020). Tekstur tanah di wilayah Provinsi Jawa Timur didominasi oleh tekstur halus dengan kategori "sesuai" sampai dengan "sangat sesuai" dengan lokasi potensial pembangunan embung sebesar 58,8\% utamanya di dataran rendah (Gambar 3).
Hal ini juga didukung oleh tekstur tanah yang kaya kandungan lumpur dan liat yang memiliki kapasitas lebih besar untuk menahan air. Hal berbeda ditunjukkan oleh lokasi pada wilayah bagian selatan. Wilayah ini didominasi oleh wilayah dengan tingkat kesesuaian "tidak sesuai" sehingga wilayah ini memiliki potensi yang rendah untuk menjadi tempat pembangunan embung didasarkan pada satu faktor tekstur tanah. 


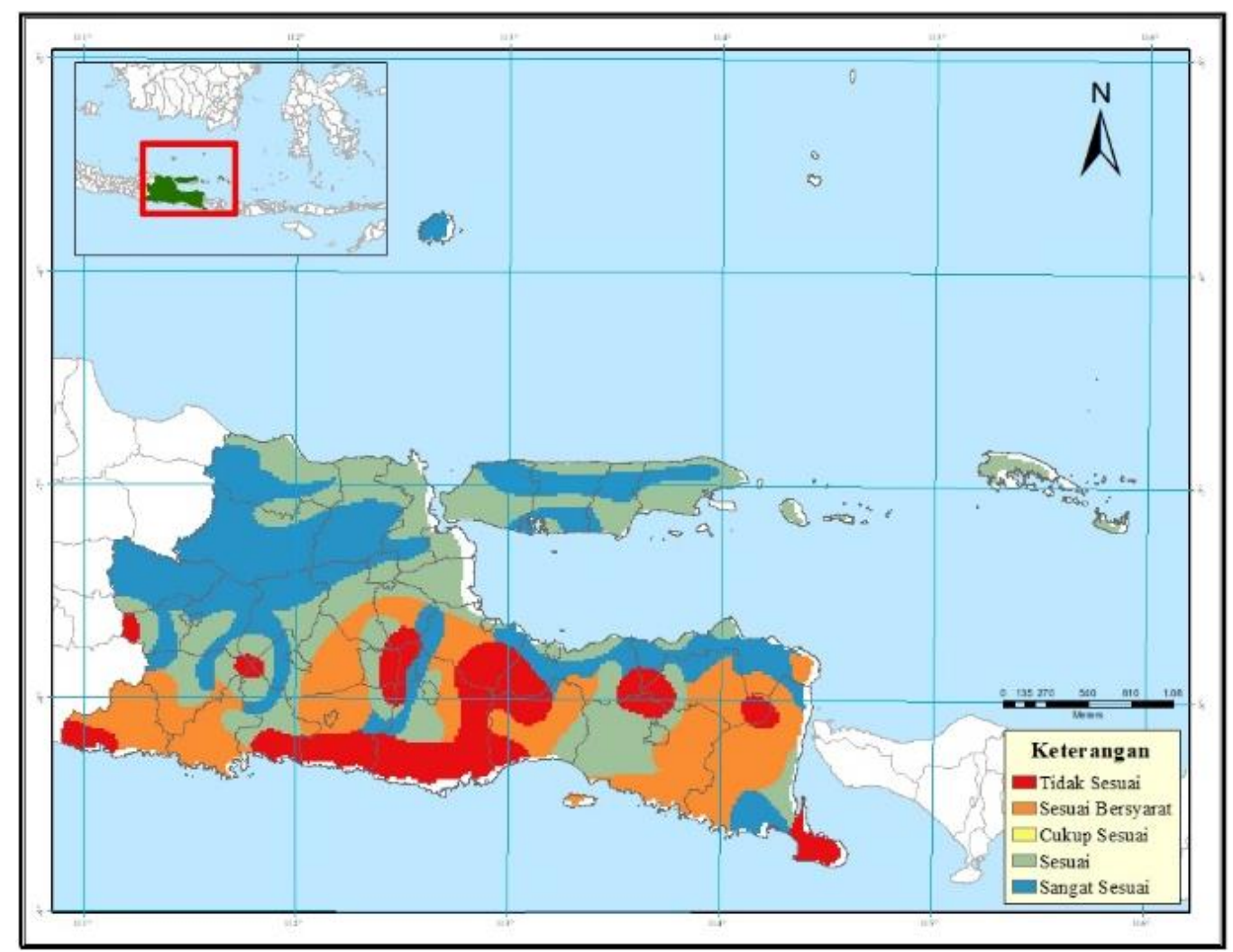

Gambar 3 Sebaran Nilai Indikator Tekstur Tanah dalam Evaluasi Pembangunan Embung di Provinsi Jawa Timur

Komponen drainase yang dianalisis berdasarkan jarak terhadap sungai menunjukkan bahwa wilayah yang memiliki jarak yang jauh dengan sungai memiliki potensi kehilangan air yang lebih tinggi dibandingkan dengan wilayah yang dekat dengan sungai. Hasil kajian yang dilakukan oleh (Tumbo et al., 2013) menunjukkan bahwa wilayah dengan jarak kurang dari atau sama dengan $500 \mathrm{~m}$ dari sungai memiliki potensi yang tinggi sebagai lokasi pemanenan air. Hal ini didukung oleh kondisi wilayah yang semakin dekat dengan sungai, potensi kehilangan air melalui proses drainase dan perkolasi semakin rendah. Hasil kajian wilayah studi menunjukkan, Provinsi Jawa Timur memiliki area sekitar $16 \%$ berada pada kategori "sangat sesuai" sebagai tempat pembangunan embung didasarkan atas kriteria jarak dari sungai. Pada sisi yang lain, sebesar $83,8 \%$ wilayah berada pada kategori wilayah yang "tidak sesuai". Nilai persentase rendah wilayah yang sesuai dengan kriteria jarak sungai disebabkan oleh karena wilayah Provinsi Jawa Timur hanya sebagian kecil wilayah yang berada dekat dengan sungai. Sebagian besar memiliki wilayah sudah berkembang dan menyebar di wilayah yang jaraknya cukup jauh dari sungai (Gambar 4). 


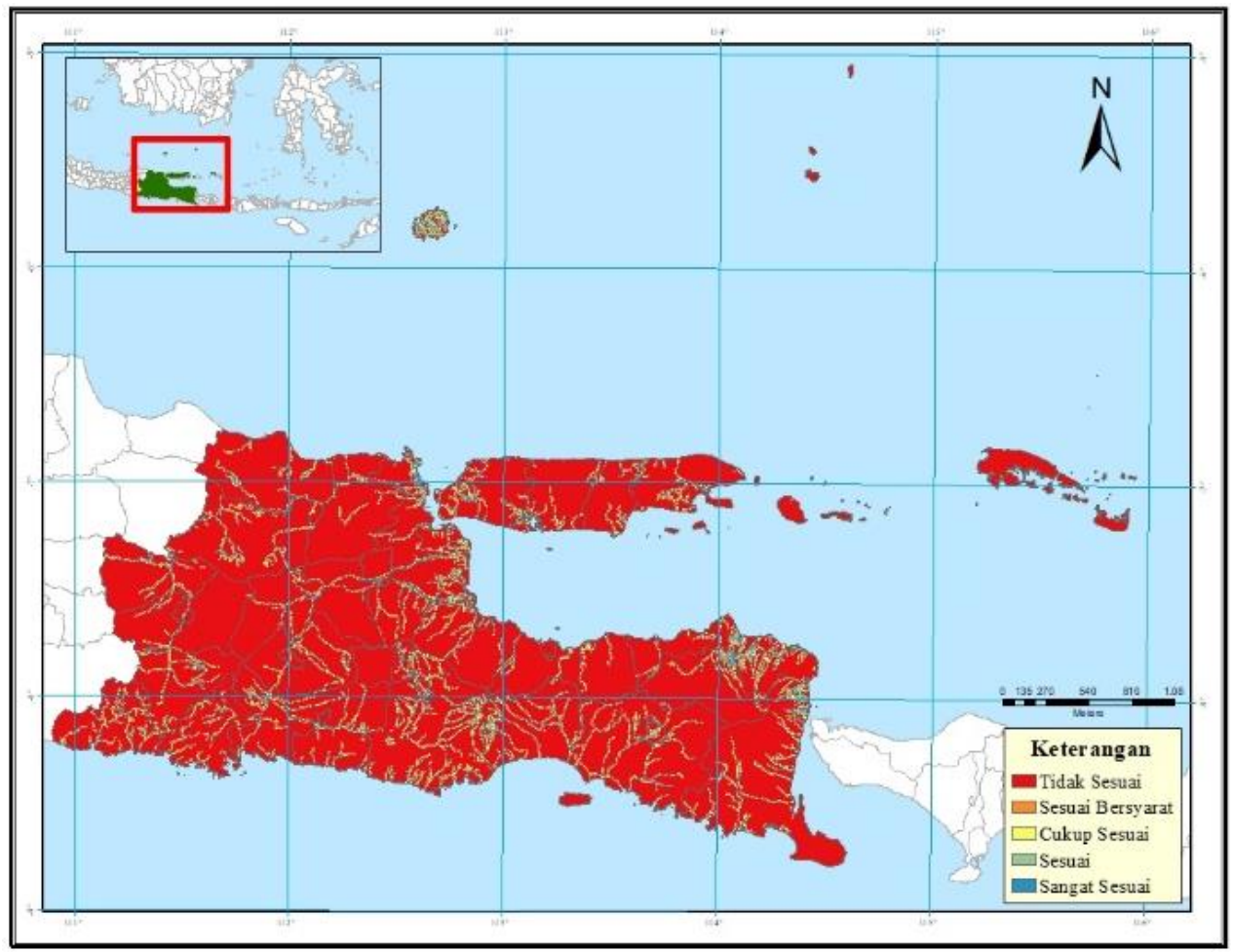

Gambar 4 Sebaran Nilai Indikator Jarak dari Sungai dalam Evaluasi Pembangunan Embung di Provinsi Jawa Timur

\section{Kesesuaian Faktor Vegetasi dalam Penentuan Lokasi Embung}

Indikator vegetasi (IVI) dalam evaluasi kesesuaian wilayah untuk pembangunan embung dianalisis dari jenis tutupan lahan. Semakin tinggi kerapatan vegetasi maka semakin tinggi kehilangan air karena proses intersepsi, penyimpanan dan infiltrasi wilayah sehingga mengurangi nilai limpasan permukaan. Berdasarkan indeks vegetasi tersebut, wilayah Provinsi Jawa Timur dikategorikan dalam kelompok "sesuai" sebesar $65 \%$ yang dominan berada di wilayah pegunungan/dataran tinggi. Hal ini sejalan dengan penelitian (Maryantika et al., 2018; Sitanggang et al., n.d.) yang menunjukkan bahwa tingkat vegetasi berbanding lurus dengan kemiringan lereng. Wilayah vegetasi tinggi di Provinsi Jawa Timur dominan berada di wilayah Jawa Timur bagian selatan seperti wilayah Trenggalek, Madiun, Batu, Probolinggo, Jember, Situbondo, dan Banyuwangi. Sebaran vegetasi yang beragam dan tersebar merata di wilayah Provinsi Jawa Timur menghasilkan peta kesesuaian yang menyebar hampir di seluruh wilayah Provinsi Jawa Timur. Demikian juga halnya dengan wilayah kategori "tidak sesuai" untuk dijadikan lokasi pemanenan air memiliki lokasi yang juga menyebar hampir diseluruh wilayah kajian (Gambar 5) 


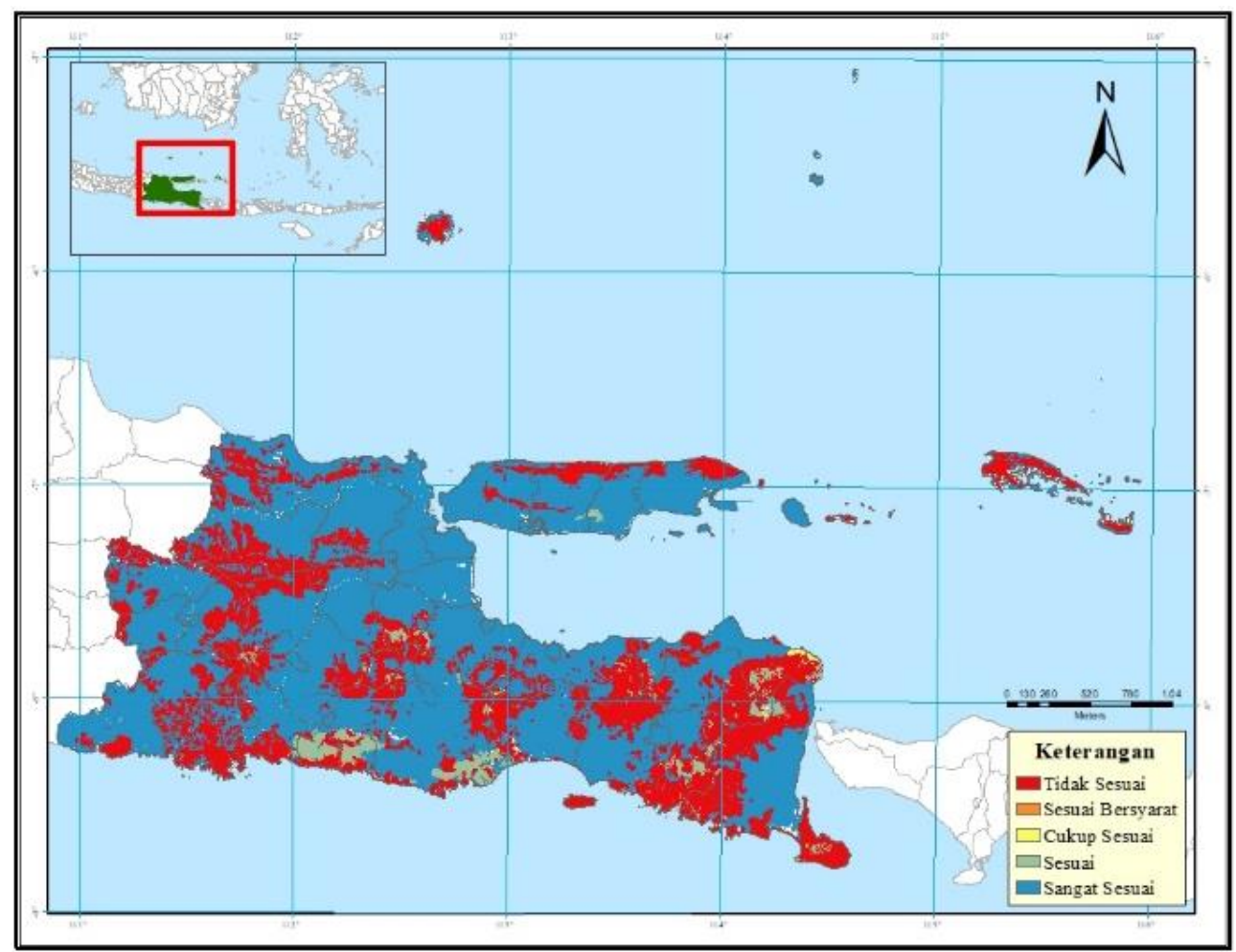

Gambar 5 Sebaran Nilai Indikator Vegetasi dalam Evaluasi Pembangunan Embung di Provinsi Jawa Timur

Evaluasi Kesesuaian Wilayah untuk Pembangunan Embung Berdasarkan Faktor Iklim, Fisik Permukaan dan Vegetasi

Evaluasi pada masing-masing indikator menunjukkan bahwa indikator iklim didominasi oleh kategori "cukup sesuai" sebesar 53,8\%. Hal ini menunjukkan curah hujan memiliki potensi tinggi untuk menjadikan wilayah kajian sebagai lokasi pembangunan embung. Hal ini sejalan dengan kajian yang menunjukkan bahwa curah hujan merupakan komponen yang memiliki kontribusi tinggi dalam menentukan wilayah sebagai lokasi pemanenan air (Subagyono et al., 2004; Suprayogi et al., 2017). Hal berbeda ditunjukkan oleh indikator fisik seperti kelerengan wilayah dan jarak dari sungai. Sebagian kecil wilayah merupakan wilayah yang "sangat sesuai" jika didasarkan atas faktor kelerengan namun merupakan wilayah yang "tidak sesuai" jika didasarkan oleh jarak dari sungai. Lebih dari $80 \%$ wilayah merupakan wilayah yang "tidak sesuai" jika didasarkan atas kelerengan wilayah karena kondisi wilayah yang didominasi oleh wilayah dengan kelerengan yang curam sehingga mengurangi kamampuan untuk menahan air. Namun demikian tekstur tanah yang juga bagian dari indikator fisik lahan menunjukkan bahwa wilayah kajian didominasi oleh kategori "sesuai" untuk menjadi wilayah pemanenan air. Sedangkan untuk indikator vegetasi, wilayah didominasi oleh lahan pertanian yang tersebar hampir diseluruh wilayah Provinsi Jawa Timur menjadikan wilayah tersebut memiliki kategori "sangat sesuai" sebagai wilayah pembangunan embung. Hasil ini menunjukkan bahwa sebaran vegetasi bukan menjadi faktor pembatas dalam pembangunan embung di wilayah tersebut. Nilai tingkat kesesuaian berdasarkan masing-masing indikator dirangkum dalam Tabel 7. 
JSIL | Santikayasa dkk. : Identifikasi Lokasi Patensial Panen Air Hujan

Tabel 7 Rangkuman Nilai Persentase Kesesuaian Wilayah untuk Pembangunan Embung Berdasarkan Indikator

\begin{tabular}{lccccc}
\hline Nilai indikator & \multicolumn{5}{c}{ Persentase Luasan (\%) } \\
\cline { 2 - 6 } & Curah & Kemiringan & Jarak & Tekstur & Tutupan \\
& Hujan & Lereng & Sungai & Tanah & Lahan \\
\hline Tidak Sesuai & 0.0 & 3.2 & 83.8 & 13.6 & 0.8 \\
\hline Sesuai Bersyarat & 24.1 & 9.2 & 4.4 & 22.9 & 32.4 \\
\hline Cukup Sesuai & 53.8 & 15.4 & 3.2 & 0.0 & 0.2 \\
\hline Sesuai & 22.1 & 25.9 & 4.2 & 30.4 & 3.2 \\
\hline Sangat Sesuai & 0.0 & 46.0 & 4.4 & 28.8 & 63.5 \\
\hline
\end{tabular}

Namun demikian, indikator tersebut tidak mampu berdiri sendiri sebagai kriteria dalam menilai tingkat kesesuaian wilayah untuk lokasi pembangunan embung. Seperti hasil kajian (Anjasmoro et al., 2016) yang menunjukkan bahwa masing-masing indikator saling melengkapi sebagai tempat pemanenan air, sehingga gabungan antar indikator merupakan pendekatan yang digunakan untuk menentukan wilayah berdasarkan tingkat kesesuaian berdasarkan kriteria wilayah secara keseluruhan. Identifikasi wilayah yang sesuai sebagai lokasi pembangunan embung berdasarkan keseluruhan nilai indikator menggunakan asumsi bahwa nilai masing-masing indikator memiliki tingkat bobot yang sama. Hasil penjumlahan indikator iklim, fisik permukaan, dan vegetasi menunjukkan bahwa wilayah provinsi Jawa Timur dominan berada pada kategori "sangat sesuai" dan "sesuai". Provinsi Jawa Timur memiliki wilayah yang "sangat sesuai" dan "sesuai" untuk pembangunan embung sebesar $63,5 \%$ dan 23,3\%. Hal ini menunjukkan bahwa potensi wilayah Jawa Timur untuk menjadi wilayah pembangunan embung sangat tinggi yaitu sebesar $86,6 \%$ dibandingkan dengan keseluruhan wilayah. Pada sisi lain, lokasi yang memiliki kategor "tidak sesuai" hanya $8,7 \%$ dari total luas Provinsi Jawa Timur. Lokasi tidak sesuai ini umumnya terdapat pada bagian utara dan timur Provinsi Jawa Timur yaitu terletak pada kecamatan Tuban, Sampang, Pamekasan, Sumenep, Bondowoso, Situbondo, dan Banyuwangi.

Namun demikian, peta kesesuaian yang diperoleh dari analisis indikator tersebut setelah ditumpangsusun dengan wilayah pemukiman menunjukkan bahwa sebagaian wilayah yang memiliki tingkat "sesuai" dan "sangat sesuai" berada di wilayah pemukiman. Evaluasi lanjutan dilakukan dengan mengkonversi kategori wilayah pemukiman yang masuk dalam kategori "sesuai" dan "sangat sesuai" menjadi wilayah dengan kategori "tidak sesuai". Hal ini sesuai dengan hasil (Adi, 2011) yang menunjukkan bahwa wilayah pemukiman tidak cocok dan memiliki potensi yang rendah untuk dijadikan wilayah pembangunan embung mengingat keterbatasan lahan yang bisa digunakan dan kompleksitas wilayah jika dikonversi menjadi embung. Hasil analisis menunjukkan bahwa wilayah dengan pemukiman tinggi tersebar dominan di Provinsi Jawa Timur bagian barat hingga tengah dengan konsentrasi sebaran wilayah pemukiman berada di 
Kota Surabaya dan Sidoarjo. Wilayah pemukiman ini banyak terdapat di wilayah dengan kesesuaian "sangat sesuai" yang tersebar di Tulungagung, Blitar, Kediri, Ngawi, Surabaya, Malang, Jember, dan Banyuwangi. Perhitungan terhadap tingkat kesesuaian setelah dikurangkan dengan wilayah yang masuk dalam pemukiman menunjukkan wilayah dengan kategori "sangat sesuai" dan "sesuai" secara berurutan sebesar $55 \%$ dan $23 \%$, sehingga secara keseluruhan tingkat kesesuaian lokasi pembangunan embung sebesar $78 \%$ seperti ditunjukkan oleh Tabel 8.

Tabel 8 Persentasi Wilayah dengan Potensi Tingkat Kesesuaian untuk Pembangunan Embung Berdasarkan Indeks Kesesuaian Embung (IKE)

\begin{tabular}{lrr}
\hline Kelas Kesesuaian & \multicolumn{2}{c}{ Persentase Luas (\%) } \\
\cline { 2 - 3 } berdasarkan nilai IKE & $\begin{array}{r}\text { Sebelum dikurangi wilayah } \\
\text { pemukiman }\end{array}$ & $\begin{array}{r}\text { Setelah dikurangi wilayah } \\
\text { pemukiman }\end{array}$ \\
\hline Sangat Tidak Sesuai & 0.0 & 9.2 \\
Tidak Sesuai & 8.8 & 8.7 \\
Sesuai & 23.3 & 23.0 \\
Sangat Sesuai & 63.5 & 55.0 \\
\hline
\end{tabular}

Evaluasi spasial dilakukan pada wilayah Provinsi Jawa Timur dengan menggunakan indikator IKL, IFP dan IVI untuk mengasilkan nilai IKE secara spasial. Wilayah tersebut juga dievaluasi dengan asumsi bahwa wilayah pemukiman memiliki potensi rendah dengan kategori "tidak sesuai" sebagai lokasi pembangunan embung. Hasil analisis ini ditunjukkan dalam peta seperti Gambar 6.

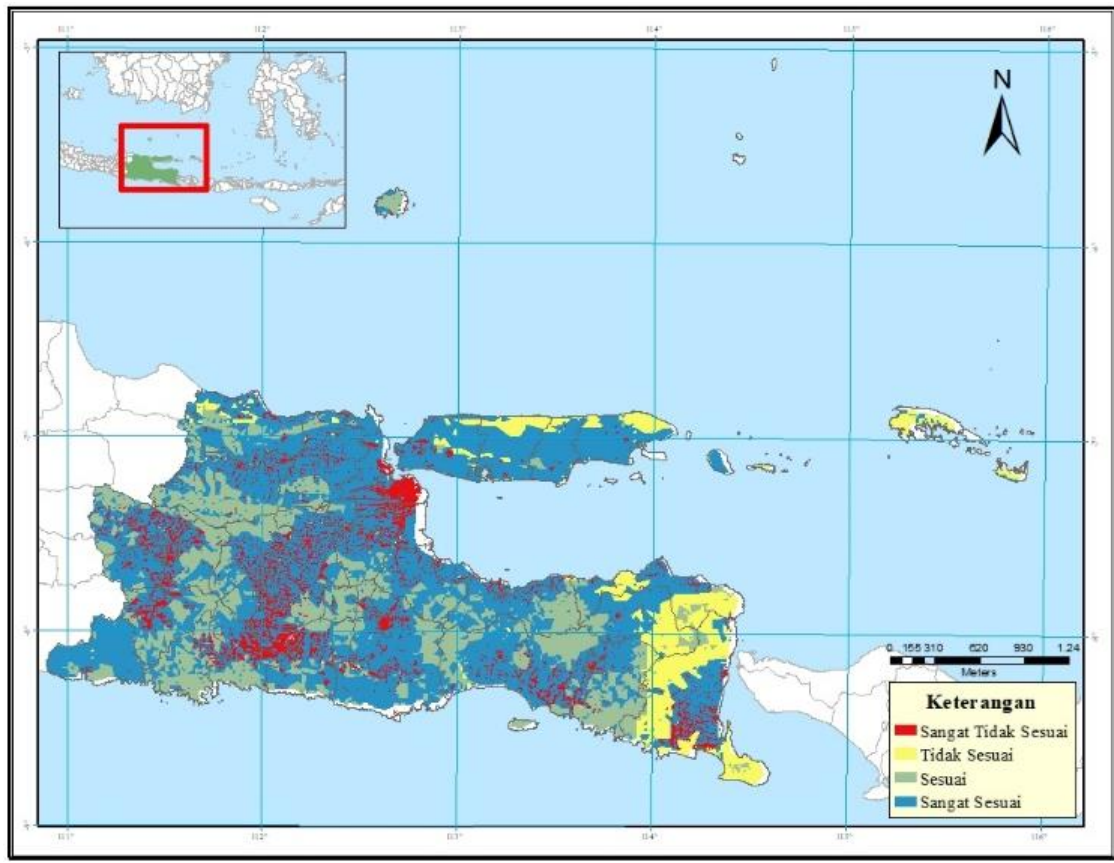

Gambar 6 Sebaran Spasial Potensi Tingkat Kesesuaian untuk Pembangunan Embung Berdasarkan Indeks Kesesuaian Embung (IKE) 
Hasil ini menunjukkan sebaran wilayah yang memiliki potensi "sangat sesuai" (biru), "sesuai" (hijau), "tidak sesuai" (kuning) dan "sangat tidak sesuai" (merah). Wilayah-wilayah yang berwarna biru mendominasi sebagian besar wilayah Provinsi Jawa Timur. Hal berbeda ditunjukkan oleh warna merah yang mendominasi wilayah bagian utara yang merupakan wilayah pantai. Kondisi dengan kategori "tidak sesuai" warna kuning mendominasi wilayah bagian timur yang merupakan wilayah pegunungan. Hal ini menunjukkan bahwa wilayah dataran rendah memiliki potensi yang lebih tinggi sebagai lokasi ppembangunan embung dibandingkan dengan lokasi dengan topografi terjal.

\section{KESIMPULAN}

Pembangunan embung di wilayah Provinsi Jawa Timur sangat dipengaruhi oleh faktor iklim khususnya curah hujan selain tekstur tanah, kelerengan wilayah, drainase wilayah dan tingkat tutupan vegetasi. Evaluasi potensi wilayah untuk pembangunan embung di Provinsi Jawa Timur menghasilkan tingkat kesesuaian pada kategori "sesuai" sampai dengan "sangat sesuai" dengan nilai sebaran sekitar 78\%. Lokasi ini tersebar di Jawa Timur bagian utara antara lain Surabaya, Lamongan, Jombang, Gresik, Tuban, Bojonegoro, Bangkalan, Sampang, Pamekasan, dan Sumenep. Sedangkan lokasi "tidak sesuai" dengan sebaran sekitar $8,7 \%$ dominan berada di wilayah Jawa Timur bagian selatan yaitu di Banyuwangi, Jember, Situbondo, Malang bagian selatan, dan Ponorogo. Wilayah Tulungagung, Blitar, Kediri, Ngawi, Surabaya, Malang, Jember, dan Banyuwangi memiliki kategori "sangat tidak sesuai" karena wilayah tersebut didominasi oleh pemukiman yang tidak memungkinkan wilayah tersebut untuk dibangun embung.

Pola hasil menunjukkan bahwa lokasi kesesuaian sangat dipengaruhi oleh karakter biofisik tanah utamanya kemiringan lereng, tekstur tanah dan tutupan lahan. Curah hujan dan jarak sungai kurang menunjukkan pola sebaran lokasi kesesuaian di Provinsi Jawa Timur.

\section{DAFTAR PUSTAKA}

Adi, H. P. (2011). Kondisi dan konsep penanggulangan bencana kekeringan di Jawa Tengah. Seminar Nasional Mitigasi Dan Ketahanan Bencana, 26, 1-10.

Adrianto, H. (2017). Lumbung Air sebagai Alternatif Penyediaan Air Baku Perkotaan (Studi Kasus: Analisis Penentuan Prioritas Lokasi Embung). Prosiding Seminar Nasional Inovasi Dalam Pengembangan SmartCity, 1(1).

Ammar, A., Riksen, M., Ouessar, M., \& Ritsema, C. (2016). Identification of suitable sites for rainwater harvesting structures in arid and semi-arid regions: A review. International Soil and Water Conservation Research, 4(2), 108-120.

Anam, K., Munibah, K., \& Sudadi, U. (2020). Strategi Pengembangan Lahan Budidaya Jagung dan Padi di Wilayah Daratan Kabupaten Sumenep, Madura, Jawa Timur. Jurnal Ilmu Tanah Dan Lingkungan, 22(2).

Anjasmoro, B., Suharyanto, S., \& Sangkawati, S. (2016). Analisis Prioritas Pembangunan Embung Metode Cluster Analysis, AHP dan Weighted Average (Studi Kasus: Embung di Kabupaten Semarang). Media Komunikasi Teknik Sipil, 21(2), 101-112. 
Budianto, M. B., Supriadi, A., Hidayat, S., \& Salehudin, S. (2020). Model Irigasi Hemat Air Perpaduan System of Rice Intensification (SRI) dengan Alternate Wetting and Drying (AWD) pada Padi Sawah. Jurnal Teknik Pengairan: Journal of Water Resources Engineering, 11(2), 128-136.

Djamhari, S. (2009). Peningkatan produksi padi di lahan lebak sebagai alternatif dalam pengembangan lahan pertanian ke luar pulau Jawa. Jurnal Sains Dan Teknologi Indonesia, 11(1).

Ginting, S., Rahmandani, D., \& Indarta, A. H. (2019). Optimasi pemanfaatan air embung Kasih untuk domestik dan irigasi tetes. Jurnal Irigasi, 13(1), 41-54.

Harini, R., Ariani, R. D., Supriyati, S., \& Satriagasa, M. C. (2019). Analisis Luas Lahan Pertanian Terhadap Produksi Padi Di Kalimantan Utara. Jurnal Kawistara, 9(1), 1527.

Hermawan, A., Purwanto, M. Y. J., \& Pandjaitan, N. H. (2020). Analisis Kesesuaian Lokasi Bendung Kecil dan Daerah Pemanenan Air Hujan (PAH) dengan Menggunakan Sistem Informasi Geogerafis (SIG) di Wilayah Perkotaan. TATALOKA, 22(2), 188-201.

Iglesias, A., \& Garrote, L. (2018). Local and collective actions for adaptation to use less water for agriculture in the mediterranean region. In Water scarcity and sustainable agriculture in semiarid environment (pp. 73-84). Elsevier.

Indriani, Y., Limantara, L. M., \& Soetopo, W. (2020). Analisis Optimasi Untuk Prioritas Pembangunan Embung Berbasis Ketersediaan Air Di Kecamatan Kedungadem Kabupaten
Bojonegoro. Jurnal Teknik Pengairan: Journal of Water Resources Engineering, 11(2), 94103.

Krisnayanti, D. S. (2018). Analisis nilai koefisien limpasan permukaan pada embung kecil untuk pertanian di pulau flores bagian timur. JURNAL SUMBER DAYA AIR, 14(2), 125-140.

Mahendra, D. D., \& Noerhayati, E. (2019). Studi Perencanaan Embung Kalipang Kabupaten Pasuruan Propinsi Jawa Timur. Jurnal Rekayasa Sipil, 6(1), 6375.

Maryantika, N., Jaelani, L. M., \& Setiyoko, A. (2018). Analisa Perubahan Vegetasi Ditinjau Dari Tingkat Ketinggian Dan Kemiringan Lahan Menggunakan Citra Satelit Landsat Dan SPOT 4 (Studi Kasus Kabupaten Pasuruan). Geoid, 7(1), 94-100.

Misnawati, M., Firda, D., \& Rachmawati, N. (2020). Potensi Tanam Padi pada Musim Kemarau 2020 di Provinsi Jawa Timur. Buletin Hasil Penelitian Agroklimat Dan Hidrologi, 17, 47-59.

Muslim, A. (2017). Prospek Ekonomi Ubi Kayu di Indonesia. Repositori Universitas Al Azhar Indonesia. Jakarta: UAI. Downloaded Fom: Http://Repository. Uai. Ac. Id/Wpcontent/Uploads/2017/10/P rospek-Ekonomi-Ubi-Kayu-DiIndonesia. Pdf.

Nasution, M. I., \& Nuh, M. (2019). Kajian Iklim berdasarkan Klasifikasi Oldeman di Kabupaten Langkat. JISTech (Journal of Islamic Science and Technology), 3(2).

Prabowo, A., Arif, S. S., Sutiarso, L., \& Purwantana, B. (2014). Model simulasi pengembangan sistem 
irigasi untuk tanaman jagung di lahan sawah dan lahan kering (studi kasus pada usahatani jagung di Kabupaten Kediri). Agritech, 34(2), 203-212.

Priyoadi, B. R., \& Setiawan, B. I. (2020). Pemetaan Topografi Calon Lokasi Embung di Kampus IPB Darmaga, Bogor. Jurnal Teknik Sipil Dan Lingkungan, 5(1), 5158.

Quist-Jensen, C. A., Macedonio, F., \& Drioli, E. (2015). Membrane technology for water production in agriculture: Desalination and wastewater reuse. Desalination, 364, 17-32.

Rahayu, N. D., Sasmito, B., \& Bashit, N. (2018). Analisis pengaruh fenomena indian ocean dipole (IOD) terhadap curah hujan di pulau Jawa. Jurnal Geodesi Undip, 7(1), 57-67.

Salli, M. K. (2019). Penerapan Teknologi Hemat Air Pada Budidaya Tanaman Semusim Lahan Kering Di Desa Baumata Timur Kabupaten Kupang. $J$ Dinamika: Jurnal Pengabdian Masyarakat, 4(1).

Santikayasa, I. P., Maesaroh, S., \& Agis. (2017). Water Allocation Based on Economic Criteria Using Aquarius Model (A Case Study in AmbangBrantas subbasin, Indonesia). Agromet, 31(2), 89-102.

Santoso, A. B. (2015). Pengaruh luas lahan dan pupuk bersubsidi terhadap produksi padi nasional. Jurnal Ilmu Pertanian Indonesia, 20(3), 208-212.

Sitanggang, R. S. H., Wahyudi, K., \& Tafonao, P. (n.d.). ANALISIS HUBUNGAN KETINGGIAN TEMPAT DENGAN JENIS DAN KLASIFIKASI FLORA DI WILAYAH HUTAN
SIBOLANGIT. Tunas Geografi, 6(2), 124-130.

Sitompul, M., \& Efrida, R. (2018). Evaluasi Ketersediaan Air Das Deli Terhadap Kebutuhan Air (Water Balanced). Jurnal Rekayasa Sipil (JRS-Unand), 14(2), 121-130.

Soerjandono, N. B. (2019). TEKNIK PENGKAJIAN VARIETAS UNGGUL BARU PADI GOGO DI LAHAN MARGINAL. Penanggung Jawab, 24(1), 53-56. Subagyono, K., Haryati, U., \& Tala'ohu, S. H. (2004). Teknologi konservasi air pada pertanian lahan kering. Dalam: Kurnia U, Rachman A, Dariah A (Eds.). Teknologi Konservasi Tanah Pada Lahan Kering Berlereng. Puslitbang Tanah Dan Agroklimat, Badan Litbangtan, 151-188.

Sudana, W. (2017). Potensi Dan Prospek Lahan Rawa Sebagai Sumber Produksi Pertanian. Potensi Dan Prospek Lahan Rawa Sebagai Sumber Produksi Pertanian, 3(2), 141-151.

https://doi.org/10.21082/akp.v3n2 .2005.141-151

Suprayogi, I., Asmura, J., \& others. (2017).

PEMANFAATAN PEMANENAN AIR HUJAN SKALA INDIVIDU UNTUK KEBUTUHAN AIR BERSIH PADA PULAU KECIL. Logic: Jurnal Rancang Bangun Dan Teknologi, 17(1), 9-15.

Sutrisno, N., \& Heryani, N. (2019). Pengembangan irigasi hemat air untuk meningkatkan produksi pertanian lahan kering beriklim kering. Jurnal Sumberdaya Lahan, 13(1), 17-26.

Tala'ohu, S. H., Heryani, N., \& Sudarman, K. (2013). Kondisi Biofisik Lahan Serta Arahan 
Teknik Konservasi Tanah Dan Air Pada Beberapa Embung Di Nusa Tenggara Timur. Bogor: Balai Penelitian Agroklimat dan Hidrologi.

Taufik, M., Kurniawan, A., \& Putri, A. R. (2016). Identifikasi Daerah Rawan Tanah Longsor Menggunakan SIG (Sistem Informasi Geografis)(Studi Kasus: Kabupaten Kediri). Jurnal Teknik ITS, 5(2), C78--C82.

Tumbo, S. D., Mbilinyi, B. P., Mahoo, H. F., \& Mkilamwinyi, F. O. (2013). Identification of suitable indices for identification of potential sites for rainwater harvesting. Tanzania Journal of Agricultural Sciences, 12(2).

Ulfah, A., \& Sulistya, W. (2015). Penentuan kriteria awal musim alternatif di wilayah Jawa Timur. Jurnal Meteorologi Dan Geofisika, 16(3).

Winahyu, N. (2020). Analisis Penentuan Komoditas Unggulan Tanaman Pangan Di Kabupaten Kediri Provinsi Jawa Timur. Jurnal Ilmiah Hijau Cendekia, 5(2), 5154. 
JSIL | Santikayasa dkk. : Identifikasi Lokasi Patensial Panen Air Hujan 